\title{
IMPROVEMENT OF BEGINNERS CAPACITY FOR BEGINNERS IN SUMENEP OF EAST JAVA, INDONESIA
}

\author{
Aziz Faisol $^{\star}$, Wisnujati Nugrahini Susantinah, Rahayu Sri \\ Wijaya Kusuma Surabaya University, Indonesia \\ *E-mail: faisolaziz366@gmail.com
}

\begin{abstract}
Farmers are the main actors in the agricultural sector production activities as well as part of the community whose welfare needs to be improved. With extension workers can help farmers in receiving all agricultural information that is developing effectively. Increasing extension programs in the development of farmer groups needs to be implemented in a participatory manner so that the principles of equality, transparency, responsibility, accountability and cooperation can become new changes in farmer empowerment. The extension worker decides to select and organize the message content and symbols used in the message. Extension techniques are selecting, arranging, simplifying, and presenting. Symbols that are easily observed and the most widely used are language. In its activities as an agent of change, it always provides directions that can raise awareness of agricultural business actors. The role of the extension worker as a facilitator, namely the role of the extension worker to create a conducive learning atmosphere for farmers, the indicators are: efforts to get farmers closer to information sources, provision of learning facilities, frequency interactions, and the methods used. The farmer group has several functions, namely as a learning class, a production unit and a vehicle for cooperation. In class learning, groups will have a close relationship and participate when planning, in implementing them, knowing the benefits and will be evaluated. Farmer groups are regulated in the Regulation of the Minister of Agriculture Number 82 of 2013 concerning Guidelines for the Development of Farmers' Groups and Farmer Group Associations which defines that "A farmer group is a group of farmers / ranchers / planters formed on the basis of common interests, equality of social, economic and natural environmental conditions., commodity commonality, and familiarity to improve and develop members' businesses. Within the farmer group, there are members of the farmer group who are referred to as the main actors and entrepreneurs.
\end{abstract}

\section{KEY WORDS}

Extension officers, farmer groups, facilitators.

Farmers are the main actors in the agricultural sector production activities as well as part of the community whose welfare needs to be improved. With extension workers can help farmers in receiving all agricultural information that is developing effectively. Increasing extension programs in the development of farmer groups needs to be carried out with a participatory nuance so that the principles of equality, transparency, responsibility, accountability and cooperation become new changes in farmer empowerment (Marbun, et al: 2019).

Extension is one of the non-formal education provided to farmers in the form of assistance to increase their productivity in farming. It is an activity to convey knowledge in agricultural development, which is expected to be a place for farmer groups to learn and to facilitate farmers in planting understanding of attitudes, and the application of modern agricultural technology (Ginting \& Andari: 2020)

The extension worker decides to select and organize the message content and symbols used in the message. Extension techniques are to select, organize, simplify, and present. Symbols that are easily observed and the most widely used are language.

In its activities as an agent of change, it always provides directions that can raise awareness of agricultural business actors (Nur Jaya: 2018). 
The role of the extension worker as a facilitator, namely the role of the extension worker to create a conducive learning atmosphere for farmers, the indicators are: efforts to get farmers closer to information sources, provision of learning facilities, frequency interactions, and methods used (Yunasaf \& Tasripin, 2011)

The farmer group has several functions, namely as a learning class, a production unit and a vehicle for cooperation. In class learning, groups will have a close relationship and participate when planning, in implementing them, knowing the benefits and will be evaluated (Ramadoan, Muljono, and Pulungan 2016)

Farmer groups are regulated in the Regulation of the Minister of Agriculture Number 82 of 2013 concerning Guidelines for the Development of Farmers' Groups and Farmer Group Associations which defines that "A farmer group is a group of farmers / ranchers / planters formed on the basis of common interests, equality of social, economic and natural environmental conditions., commodity commonality, and familiarity to improve and develop members' businesses. Within the farmer group, there are members of the farmer group who are referred to as the main actors and entrepreneurs.

\section{METHODS OF RESEARCH}

The research was conducted at farmer groups in Pasongsongan District, Sumenep Regency, East Java, Indonesia. The choice of research location was determined purposively, with the consideration that the area in Pasongsongan Subdistrict, Sumenep Regency, is a potential area for agricultural production activities, both from its strategic natural factors, as well as from the factor of land area which is larger than other areas. As an agricultural pontesial area, the farmer groups in Pasongsongan Subdistrict have 282 farmer groups with various class levels, and are only assisted by 5 PPL people. The research was carried out from October 2020 to January 2021

Data sources are primary and secondary. Sources of data were obtained from extension agents and respondent farmers through interviews using questionnaires and direct field observations.

Secondary data from farmers: consists of farmer identity including: name, age, gender, latest education, land area, land ownership, group position. The data obtained from the extension agents include the identity of the extension agents: name, age, gender, length of time as extension agents, and activities of the extension workers. Data from the management of farmer groups: Identity of farmer group members, farmer group activities, and farmer group records Secondary data collection was obtained from literature from agencies, namely: the Central Statistics Agency of Sumenep Regency, the Technical Service Unit of the Agricultural Extension Implementing Agency, Pasongsongan District, Sumenep Regency, the Pasongsongan District Office, Sumenep Regency.

Table 1 - Variable Measurement Indicators for the Role of Extension Officers as Facilitators in Farmer Groups in Sumenep, East Java, Indonesia

\begin{tabular}{|c|c|c|c|}
\hline Variable & Indicator & Criteria & Score \\
\hline \multirow{3}{*}{$\begin{array}{l}\text { Extension } \\
\text { Facilitator }\end{array}$} & $\begin{array}{l}\text { Serving the needs of farmer groups / facilitating as needed by } \\
\text { farmers }\end{array}$ & $\begin{array}{l}\text { Very high } \\
\text { High } \\
\text { Enough/moderate } \\
\text { Low } \\
\text { Very low }\end{array}$ & $\begin{array}{l}5 \\
4 \\
3 \\
2 \\
1\end{array}$ \\
\hline & $\begin{array}{l}\text { Provide facilities and infrastructure for farmers to support their } \\
\text { farming activities }\end{array}$ & $\begin{array}{l}\text { Very high } \\
\text { High } \\
\text { Enough / moderate } \\
\text { Low } \\
\text { Very low }\end{array}$ & $\begin{array}{l}5 \\
4 \\
3 \\
2 \\
1\end{array}$ \\
\hline & $\begin{array}{l}\text { Extension workers must be open in responding to farmers' } \\
\text { complaints in developing farmer groups. }\end{array}$ & $\begin{array}{l}\text { Very high } \\
\text { High } \\
\text { Enough / moderate } \\
\text { Low } \\
\text { Very low }\end{array}$ & $\begin{array}{l}5 \\
4 \\
3 \\
2 \\
1\end{array}$ \\
\hline
\end{tabular}

Source: Primary Data, 2021 
The population is farmer groups in 10 villages throughout Pasongsongan District, the population of farmer groups with a total of 282 farmer groups in Pasongsongan district, taken $10 \%$ from 282 farmer groups to 30 respondents. The population of extension workers was only 5 people taken entirely as respondents.

Sampling was carried out purposively on the grounds that there were different levels of the role of extension workers from each class level. The selected farmer groups were beginner farmer groups. The role of the extension worker as facilitator is measured by determining specific indicators (Table 1).

The development of farmer groups will be tested when the activities of the farmer groups are directed not to focus on just one activity, but there are development activities in various aspects, such as the development of the human resources of the farmer groups. Lini et al (2018)

The development of farmer groups is a support for agricultural preservation and knowledge of matters relating to information on technological updates, utilization of natural resources in terms of technical management, the role of field agricultural extension agents (PPL), which are expected to be able to assist farmer groups in various sectors of problems in the field, also be able to provide directions for utilizing natural resources.

Agricultural extension workers are very aware that the development of human resources as manpower for managing a farm, it is necessary to form a farmer group to make it easier to develop.

Table 2 - Measurement Indicators for the Development of Beginner Farmer Groups in Sumenep, East Java, Indonesia

\begin{tabular}{|c|c|c|c|}
\hline Variable & Indicator & criteria & Score \\
\hline \multirow{6}{*}{$\begin{array}{l}\text { Development } \\
\text { Farmers }\end{array}$} & $\begin{array}{l}\text { Administrative completeness as evidenced by the existence } \\
\text { of: guest book, member list book, meeting attendance book, } \\
\text { meeting minutes, cash book, savings book, savings and } \\
\text { loan book, inventory book, information book, notebook, } \\
\text { activity results }\end{array}$ & $\begin{array}{l}\text { Very Complete } \\
\text { Complete } \\
\text { Quite complete } \\
\text { Incomplete } \\
\text { Not yet have a } \\
\text { management at all }\end{array}$ & $\begin{array}{l}5 \\
4 \\
3 \\
2 \\
1\end{array}$ \\
\hline & $\begin{array}{l}\text { Management Composition: Chairperson, treasurer, } \\
\text { secretary and members }\end{array}$ & $\begin{array}{l}\text { Very Complete } \\
\text { Complete } \\
\text { Quite complete } \\
\text { Incomplete } \\
\text { Not yet have a } \\
\text { management at all }\end{array}$ & $\begin{array}{l}5 \\
4 \\
3 \\
2 \\
1\end{array}$ \\
\hline & $\begin{array}{l}\text { Capital (Group cash) } \\
\text { Social gathering (savings and loans) } \\
\text { Farmers card }\end{array}$ & $\begin{array}{l}\text { Very easy } \\
\text { Easy } \\
\text { Quite easy } \\
\text { Difficult } \\
\text { Very difficult }\end{array}$ & $\begin{array}{l}5 \\
4 \\
3 \\
2 \\
1\end{array}$ \\
\hline & $\begin{array}{l}\text { Collaboration and Meetings by Conducting mutual } \\
\text { cooperation and conducting study classes so that farmers } \\
\text { understand better how to increase farmers' income }\end{array}$ & $\begin{array}{l}\text { Very often } \\
\text { Often } \\
\text { Often enough } \\
\text { Never } \\
\text { Very never }\end{array}$ & $\begin{array}{l}5 \\
4 \\
3 \\
2 \\
1\end{array}$ \\
\hline & $\begin{array}{l}\text { The development of farming utilizes the resulting rice straw } \\
\text { into organic fertilizer }\end{array}$ & $\begin{array}{l}\text { Very high } \\
\text { High } \\
\text { Enough / moderate } \\
\text { Low } \\
\text { Very low }\end{array}$ & $\begin{array}{l}5 \\
4 \\
3 \\
2 \\
1\end{array}$ \\
\hline & $\begin{array}{l}\text { Utilizing the selling value of production and analyzing } \\
\text { market prospects to be able to achieve economic growth }\end{array}$ & $\begin{array}{l}\text { Very high } \\
\text { High } \\
\text { Enough / moderate } \\
\text { Low } \\
\text { Very low }\end{array}$ & $\begin{array}{l}5 \\
4 \\
3 \\
2 \\
1\end{array}$ \\
\hline
\end{tabular}

Source: Primary Data, 2021. 
The $T$ statistical test is basically to show how far a variable is, to compare the significant value with the level used with the following conditions:

- If sig. $T<0.05$ So $\mathrm{H}_{0}$ is rejected and $\mathrm{H}_{1}$ is accepted;

- If sig. $T>0.05$ Then $\mathrm{H}_{0}$ is accepted and $\mathrm{H}_{1}$ is rejected;

- If $\mathrm{H}_{0}$ is accepted, it means that $X_{1} X_{2} X_{3}$ and $X_{4}$ partially have no significant effect on $Y$;

- If $H_{1}$ is accepted, it means that $X_{1} X_{2} X_{3}$ and $X_{4}$ partially have a significant effect on $Y$.

Data analysis used in this study is Kendall tau correlation is a way to determine the relationship between two variables that have an ordinal scale with data in the form of scores that can be ranked or to determine the relationship between the research variables.

The correlation hypothesis testing technique used is the t test, which is done by collecting data on farmer groups to find out:

- Does the agricultural extension's role as facilitator have anything to do with the development of farmer groups;

- Whether the development of beginner, continued, intermediate and main class farmer groups has a bearing on the role of agricultural extension agents as facilitators.

The t test coefficient testing technique is used with the following formula:

$$
\tau=\frac{S}{\frac{1}{2} n(n-1)}
$$

Where:

- $\tau=$ The Kendall tau coefficient value;

- $s=$ The numerator derived from the number of harmonization and the disordance level as a whole;

- $\mathrm{n}=$ number of samples;

- $1,2=$ constants.

\section{RESULTS AND DISCUSSION}

The role of the extension worker as a facilitator in the beginner farmer groups must be able to provide direction and assistance that emphasizes the aspects of the ability of farmer group business planning and organizational skills because they are considered beginners. In this study, it will be known the attachment or correlation between the role of the extension worker as a facilitator and the development of beginner farmer groups in Table 3.

Table 3 - Correlation of the Role of Extension Officers as Facilitators in Beginner Groups

Correlations

\begin{tabular}{|lll|l|l|}
\hline & & FACILITATOR & GROWTH \\
\hline & FACILITATOR & Correlation Coefficient & 1,000 &,- 015 \\
& & Sig. (2-tailed) &, 916 \\
& $\mathrm{~N}$ & 50 & 50 \\
\cline { 3 - 5 } Kendall's tau_b & Correlation Coefficient &,- 015 & 1,000 \\
& GROWTH & Sig. (2-tailed) &, 916 &. \\
& & $\mathrm{~N}$ & 50 & 50 \\
& & &
\end{tabular}

From the results of the Kendall's T correlation test, it can be seen that the value obtained is significant 2 tailed is $0.916>0.05$, so there is no relationship between the extension worker as a facilitator and the development of the novice group, meaning that this study shows the role of extension personnel as a facilitator in the development of novice farmer groups weak because it is considered not facilitating beginner farmer groups.

The role of the extension worker as a facilitator in the follow-up group must support matters related to sustainability, such as sustainable agriculture, sustainable production must emphasize group development because of its active value.In this study, it will be known the 
attachment or correlation between the role of the extension worker as a facilitator and the development of further farmer groups in table 4.

Table 4 - Correlation of the Role of Extension Officers as Facilitators in the Advanced Group Correlations

\begin{tabular}{|lll|l|l|}
\hline & & FACILITATOR & GROWTH \\
\hline & FACILITATOR & Correlation Coefficient & 1,000 &, $265^{*}$ \\
& & Sig. (2-tailed) &, 037 \\
& $N$ & 60 & 60 \\
\cline { 2 - 5 } Kendall's tau_b & Correlation Coefficient &, $265 *$ & 1,000 \\
& GROWTH & Sig. (2-tailed) &, 037 & 6 \\
& & $N$ & 60 & 60 \\
& & &
\end{tabular}

*. Correlation is significant at the 0.05 level (2-tailed).

It can be seen from the table above that there is a significant value of 2 tailed which is $0.037<0.05$, so there is a relationship between extension workers as facilitators and advanced group development. From the Coefficient Correlation data, the role of extension personnel as facilitators with further group development is 0.265 or the relationship is sufficient, assessed Extension officers provide control and facilitate infrastructure for farmer groups.

The role of extension workers as facilitators must facilitate every need of farmer groups, the role of extension workers as facilitators must also be able to identify problems faced by farmers, extension agents must be a liaison between several parties who will support the development of farmer groups, in farmer groups, assistance is needed that emphasizes the aspect of capability farmer group business planning and organizational skills. In this study, it will be known the attachment or correlation between the role of the extension worker as a facilitator and the development of farmer groups in table 5 below:

Table 5 - Correlation of the Role of Extension Officers as Motivators in Intermediate Groups Correlations

\begin{tabular}{|c|c|c|c|c|}
\hline & & & FACILITATOR & GROWTH \\
\hline \multirow{2}{*}{ Kendall's tau_b } & FACILITATOR & $\begin{array}{l}\text { Correlation Coefficient } \\
\text { Sig. (2-tailed) } \\
\mathrm{N}\end{array}$ & $\begin{array}{l}1,000 \\
40\end{array}$ & $\begin{array}{l}335^{*} \\
, 034 \\
40\end{array}$ \\
\hline & $\overline{\text { GROWTH }}$ & $\begin{array}{l}\text { Correlation Coefficient } \\
\text { Sig. (2-tailed) } \\
\mathrm{N}\end{array}$ & $\begin{array}{l}335^{*} \\
034 \\
40\end{array}$ & $\begin{array}{l}1,000 \\
40\end{array}$ \\
\hline
\end{tabular}

*. Correlation is significant at the 0.05 level (2-tailed).

It can be seen from the table above that there is a significant value of 2 tailed is 0.034 $<0.05$, so there is a relationship between extension agents as facilitators and middle group development and infrastructure.

The role of extension workers as facilitators must facilitate every need of farmer groups, the role of extension workers as facilitators must also be able to identify problems faced by farmers, extension agents must be a liaison between several parties who will support the development of farmer groups, in farmer groups, assistance is needed that emphasizes the aspect of capability farmer group business planning and organizational skills. In this study, it will be known the relationship or correlation between the role of the extension worker as a facilitator and the development of the main farmer groups in the following table.

It can be seen from the table above that there is a significant value of 2 tailed is 0.002 $<0.05$, so there is a relationship between extension workers as facilitators and the development of the main farmer groups, farmers assess the role of agricultural extension agents in providing facilities and providing facilities and infrastructure to the main farmer groups. 
Table 6 - Correlation of the Role of Extension Officers as Facilitators in the Main Group

\begin{tabular}{|c|c|c|c|c|}
\hline & & & |FACILITATOR & GROWTH \\
\hline \multirow[b]{2}{*}{ Kendall's tau_b } & FACILITATOR & $\begin{array}{l}\text { Correlation Coefficient } \\
\text { Sig. (2-tailed) } \\
\mathrm{N}\end{array}$ & $\begin{array}{l}1,000 \\
20\end{array}$ & $\begin{array}{l}668^{* *} \\
002 \\
20\end{array}$ \\
\hline & $\overline{\text { GROWTH }}$ & $\begin{array}{l}\text { Correlation Coefficient } \\
\text { Sig. (2-tailed) } \\
\mathrm{N}\end{array}$ & $\begin{array}{l}, 668^{* *} \\
002 \\
20\end{array}$ & $\begin{array}{l}1,000 \\
20\end{array}$ \\
\hline
\end{tabular}

${ }^{* *}$. Correlation is significant at the 0.01 level (2-tailed).

\section{CONCLUSION}

The level of the role of agricultural extension agents in the development of farmer groups in each group class in the Pasongsongan sub-district, Sumenep Regency is quite enough.

The relationship between the roles of agricultural instructors in developing farmer groups according to group class levels is seen from the role of agricultural extension agents as facilitators, innovators, motivators, dynamists and educators.

- Beginner farmer groups are able to provide positive values as innovators and dynamics in the development of novice farmer groups;

- Further farmer groups provide positive values as facilitators and innovators for further development of farmer groups;

- The middle farmer groups give positive values only as a facilitator for the development of the middle farmer groups;

- The main farmer groups have positive values as facilitators, innovators, motivators and dynamists. Negative values or no relationship are only as educators.

The extension worker conducts empowerment by facilitating and providing services and accompaniment to farmer groups by applying various strategies.

\section{SUGGESTIONS}

Based on research on the role of agricultural extension agents in the development of farmer groups in Pasongsongan District, Sumenep Regency District, the suggestions given are:

- The government must pay more attention to agricultural extension programs throughout Indonesia, the role of extension workers in carrying out activities must be continuous and provide guidance and assistance to farmers, extension workers must accelerate the flow of information to farmers about new technology and the government must know the assistance submitted by farmers quickly, on time and on target;

- Farmers must be able to adapt to new technology, farmers must also be familiar with the application of agricultural systems that have not been done before, farmers not only expect assistance from the government, but farmers are more likely to follow directions from extension agents and follow routine programs that are useful to support sustainable agricultural productivity.

\section{LIMITATIONS AND RECOMMENDATIONS}

The research has limitations and problems that need to be considered in this study, this research was conducted during the COVID-19 pandemic so there are limitations to conducting routine meetings such as those held for 1 week or once every month, because it has been set within the limit of visits and meetings, pandemic This is a limitation so that in data collection there is an agreement that has been agreed upon in advance with the party 
that is used as material for observation such as the Constraints in developing farmer groups, namely facilities and infrastructure, the distance between the offices of the Agricultural Extension Center and the number of PPLs (Field Agricultural Instructors), which are only 5 people, are a factor in constraining the development of farmer groups.

\section{REFERENCES}

1. Central Bureau of Statistics. (2018) Pasongsongan District in Figures 2018: Central Bureau of Statistics of Sumenep Regency.

2. Ginting, Nina Maksimiliana. and Gardis Andari (2020) "The Role of Agricultural Extension in the Development of Rice Farming" Journal Agricola-Vol 10 (1) March: 2020. Page 19 24 e-ISSN: 2354 - 77311 Agribusiness Department. Faculty of Agriculture. Musamus University. Merauke Indonesia.

3. Lini, La. Awaluddin Hamzah. Sukmawati Abdullah (2018) "The Role of Agricultural Extension in the Development of Farmer Groups in Benua Nirae Village, Abeli District, Kendari City" Scientific Journal of Developing Villages and Agriculture (2018) - Vol: 3 (5): 128-132 Department of Agribusiness. UHO Faculty of Agriculture.

4. Marbun, Desy Natasha VD Sriroso Satmoko, Siwi Gayatri. (2019) "The Role of Agricultural Extension in the Development of Horticultural Crop Farmer Groups in Siborongborong District, Tapanuli Regency". Journal of Agricultural Economics and Agribusiness- Volume 3, Number 3 (2019): 537-546 Faculty of Animal Husbandry and Agriculture. Diponegoro University.

5. Nur Jaya, Muhammad (2018) "The Existence of Agricultural Instructors in Implementing Participatory Development Communication for Empowerment of Farmers" Journal of Integrated Agribusiness - Vol. 11 No. December 22018 College of Communication Sciences. Muhammadiyah Jayapura. Papua Province.

6. Ramadoan, Sri. Pudji Muljono, Ismail Pulungan. 2016. "The Role of PKSM in Improving Farmer Group Functions and Community Participation in Kabupaten Bima, NTB." Journal of Forestry Social and Economic Research 10 (3): 199-210.

7. Regulation of the Minister of Agriculture Number 82 of 2013. Concerning Guidelines for the Development of Farmer Groups and Association of Farmer Groups. BKP5K Bogor Regency (ID).

8. Sugiyono. (2017). Quantitative Research Methods, Qualitative, and R \& D. Bandung: Alfabeta.

9. Sugiyono. (2015). Educational Research Methods (Quantitative Qualitative Approaches and R \& D).CV. Alfabeta: Bandung.

10. Yunasaf, unang and didin s tasripin (2011) "The Role of Extension in the Learning Process of Dairy Farmers at KSU Tandangsari Sumedang (Role of Extension Agents in Dairy smallholder farmer learning process at KSU Tandangsari Sumedang" Journal of Animal Science-Vol. 11, No. 2., 98-103, December 2011 Faculty of Animal Husbandry, Padjadjaran University. 